NBER WORKING PAPER SERIES

\title{
REPUGNANCE AS A CONSTRAINT ON MARKETS
}

\author{
Alvin E. Roth \\ Working Paper 12702 \\ http://www.nber.org/papers/w12702 \\ NATIONAL BUREAU OF ECONOMIC RESEARCH \\ 1050 Massachusetts Avenue \\ Cambridge, MA 02138 \\ November 2006
}

I have had long helpful conversations with Nava Ashraf, George Baker, Greg Barron, Eric Budish, Frank Delmonico, Drew Fudenberg, Ben Greiner, Rakesh Khurana, Steve Leider, Muriel Niederle, Eva Myersson Milgrom, Michael Rees, Susan Saidman, Dov Samet, Guhan Subramanian, Steve Woodle and seminar participants and coffee drinkers at the University of Chicago and Harvard. Some of this work has been supported by grants from the National Science Foundation. The views expressed herein are those of the author(s) and do not necessarily reflect the views of the National Bureau of Economic Research.

(C) 2006 by Alvin E. Roth. All rights reserved. Short sections of text, not to exceed two paragraphs, may be quoted without explicit permission provided that full credit, including $(\subset$ notice, is given to the source. 
Repugnance as a Constraint on Markets

Alvin E. Roth

NBER Working Paper No. 12702

November 2006

JEL No. A10,C78,D62,D63,I11

\title{
$\underline{\text { ABSTRACT }}$
}

This essay examines how repugnance sometimes constrains what transactions and markets we see. When my colleagues and I have helped design markets and allocation procedures, we have often found that distaste for certain kinds of transactions is a real constraint, every bit as real as the constraints imposed by technology or by the requirements of incentives and efficiency. I'll first consider a range of examples, from slavery and indentured servitude (which once were not as repugnant as they now are) to lending money for interest (which used to be widely repugnant and is now not), and from bans on eating horse meat in California to bans on dwarf tossing in France. An example of special interest will be the widespread laws against the buying and selling of organs for transplantation. The historical record suggests that while repugnance can change over time, change can be quite slow.

\author{
Alvin E. Roth \\ Harvard University \\ Department of Economics \\ Littauer 308 \\ Cambridge, MA 02138-3001 \\ and NBER \\ aroth@hbs.edu
}


Why can't you eat horse or dog meat in a restaurant in California, a state with a population that hails from all over the world, including some places where such meals are appreciated? The short answer is that it's against the law. ${ }^{2}$ The longer answer is that sufficiently many Californians not only don't wish to eat horses or dogs themselves, but find it repugnant that you should do so, and it is this repugnance that was enacted into law in 1998 , by popular referendum. ${ }^{3}$ The measure passed by a margin of $60 \%$ to $40 \%$, with over 4.6 million people voting for it (almost the same number as voted for the winning candidate for governor that year). ${ }^{4}$

This law is different from those that seek to protect consumers by governing the slaughter, sale, preparation and labeling of animals used for food. And it is different from laws prohibiting the inhumane treatment of animals, including animals that are routinely slaughtered for food. ${ }^{5}$ It is not illegal in California to kill horses or dogs, although the California law outlaws such killing "if that person knows or should have known that any part of that horse will be used for human consumption." Note that the prohibited use is "human consumption," it is apparently legal in California to buy and sell pet food that contains horse meat (although the use of horse meat in pet food has apparently declined in the face of the demand for U.S. horse meat in Europe, for human consumption.)

As this example makes clear, some kinds of transactions are repugnant in some times and places and not in others. This essay examines repugnance and its consequences for what transactions and markets we see. When my colleagues and I have helped design markets and allocation procedures, we have often found that distaste for certain kinds of transactions is a real constraint, every bit as real as the constraints imposed by technology or by the requirements of incentives and efficiency. In this essay I'll first consider a wide range of examples, and then focus on how ideas about inappropriate transactions have served as constraints on market design.

This will bring me naturally to the question of kidney transplantation, which will connect this essay with the others on organ transplantation in this issue. Because healthy people

\footnotetext{
${ }^{2}$ California Penal Code Section 598 states in part “...horsemeat may not be offered for sale for human consumption. No restaurant, cafe, or other public eating place may offer horsemeat for human consumption." Violation is a felony, punishable by lengthy imprisonment. It further states that "Every person is guilty of a misdemeanor who possesses, imports into, or exports from, this state, sells, buys, gives away, or accepts any carcass or part of any carcass of any animal traditionally or commonly kept as a pet or companion with the intent of using or having another person use any part of that carcass for food."

${ }^{3}$ Note that this is a repugnance that criminalizes actions by those who do not themselves find the action repugnant. (No doubt there is also widespread repugnance to the eating of cockroaches, but no law addresses that; the repugnance itself reduces the demand to zero.) The referendum was Proposition 6 in the November, 1998 ballot (see http://vote98.ss.ca.gov/VoterGuide/Propositions/6text.htm ). There have been periodic attempts to enact similar federal laws. Most recently, on September 7, 2006 the House passed, by a vote of $351-40$, and sent to the Senate H.R. 503 "To ... prohibit the shipping, transporting, moving, delivering, receiving, possessing, purchasing, selling, or donation of horses and other equines to be slaughtered for human consumption."

${ }^{4}$ See http://vote98.ss.ca.gov/Returns/prop/00.htm .

${ }^{5}$ In this respect it is different from, say, the recently established (and still contested) ban on selling foie gras in Chicago restaurants (cf Ruethling, 2006), which seems to have been inspired much more directly by repugnance to cruelty to animals, as are laws against organized fox hunts, cock fights, etc.

${ }^{6}$ In fact possession with intent is prohibited.
} 
have two kidneys and can remain healthy with only one, kidneys from living donors are now widely used for kidney transplantation, the preferred treatment for end stage renal disease. However, it is against the law to buy or to sell a kidney. I will argue that this reflects a reasonably widespread repugnance, and that this repugnance may make it difficult for arguments that focus only on the gains from trade to make headway in changing the law prohibiting a monetized market for kidneys.

That does not mean that economics and market design cannot be brought to bear, and I will describe the kidney exchange programs that Tayfun Sonmez and Utku Unver and I have helped to design in New England and elsewhere. In the simplest form of kidney exchange, a patient with a willing donor who has an incompatible blood type (or who is incompatible for another reason) can exchange a kidney with another such incompatible patient-donor pair. (That is, the pairs are matched so that the donor from one pair is compatible with the patient from the other, and each patient receives a kidney from the other patient's donor.) This sort of "in kind" exchange has gained acceptance in the transplant community. ${ }^{7}$

More generally, this essay will explain why I think we need to understand better and engage more with the phenomenon of "repugnant transactions", which, I will argue, often serves as an important constraint on markets and market design.

\section{Repugnant markets:}

Table 1 lists further examples of transactions, and markets, in which it appears that repugnance has established important constraints, presently or at some time in the past. The arrow of time points in both directions: there are markets that are repugnant today that once were not (or not sufficiently to serve as a binding constraint). And there are markets that are not widely repugnant today that once were.

\section{[Table 1 about here]}

Slavery is an obvious example of a market that is now repugnant and illegal even in places (like the United States) where such markets were once openly conducted. Indentured servitude - irrevocable service voluntarily entered for a specified period--is another. ${ }^{8}$ And so, even apart from the fact that a typical slavery transaction involves a third party, the slave, who we now recognize as a person with rights to be protected, we find absolute or near absolute servitude so repugnant that a person may not even sell him or her self into slavery, or the near slavery of indentured servitude. But indentured

\footnotetext{
${ }^{7}$ See Roth, Sonmez, and Unver (2004, 2005a,b, 2007), Saidman, Roth, Sonmez, Unver, and Delmonico (2006), and Roth, Sonmez, Unver, Delmonico, and Saidman (2006) for discussions of the issues involved in organizing kidney exchange on an efficient scale. A very small number of individual kidney exchanges had been conducted before the issue of efficient organization was raised, giving an early indication that this kind of exchange did not arouse the repugnance associated with monetary payments for organs.

${ }^{8}$ The $13^{\text {th }}$ amendment to the Constitution of the United States, passed in 1865, states "Neither slavery nor involuntary servitude, except as a punishment for crime whereof the party shall have been duly convicted, shall exist within the United States, or any place subject to their jurisdiction." Courts have interpreted it as also outlawing indentured servitude.
} 
servitude was once one of the common ways for Europeans to buy passage across the Atlantic to America. ${ }^{9}$

Lending money for interest is an example of a market that was once widely repugnant, and no longer is, (with the important exception that Islamic law is commonly interpreted as prohibiting it). State usury laws in the U.S. and Islamic banks in some Islamic countries are examples of modern expressions of this repugnance. Near the beginning of his essay "The Spirit of Capitalism," Max Weber quotes Benjamin Franklin on the virtues of responsible lending and borrowing, and near the end of the essay Weber asks "Now, how could activity, which was at best ethically tolerated, turn into a calling in the sense of Benjamin Franklin?"10 Weber goes on to argue that the repugnance of lending money for interest in some times and places and not in others is something more than a simple adaptation to financial circumstances. ${ }^{11}$

The changing repugnance of debt and of involuntary servitude have even interacted, in changes in bankruptcy law. In colonial America and the early years of the Republic, insolvent debtors could be imprisoned, or sentenced to indentured servitude (cf. Coleman, 1974). But as involuntary servitude became more repugnant, and debts less repugnant, bankruptcy laws were rewritten to provide protection to the debtor as well as to the creditor.

The examples in Table 1, and some of the others I will discuss, reflect that, even when there may be willing suppliers and demanders of certain kinds of transactions, aversion to those transactions by others may seriously constrain or even prevent them. In Table 1, "repugnance" or even "revulsion" is often exactly the right word for how some transactions are or were once regarded. In other examples, a milder word would be more apt: some transactions are seen as distasteful, inappropriate, unfair, undignified, or unprofessional

Of course, there may also be other reasons to object to markets that some people find repugnant, and so it may be difficult to attribute a single cause to the limits on certain markets at some times. For example, while hiring mercenaries was once an accepted way of dealing with military affairs, it has largely fallen out of favor since the rise of states

\footnotetext{
${ }^{9}$ Cf. Galenson (1981). In the United States, slaves were African while indentured servants were European, so the distaste for involuntary servitude is not directly related to the changing repugnance of racial discrimination. But separating markets by race (e.g. restaurants, or sports leagues) is another example of how a practice once not so repugnant and now repugnant changed the way various markets are organized.

${ }^{10}$ Weber 1930, page 74. Hirschman paraphrases Weber's question as "How did commercial, banking, and similar money-making pursuits become honorable at some point in the modern age after having stood condemned or despised as greed, love of lucre, and avarice for centuries past?" (Hirschman, 1977, 97, page 9)

11 "The fact to be explained historically is that in the most highly capitalistic center of that time, in Florence of the fourteenth and fifteenth centuries, the money and capital market of all the great political Powers, this [Franklin's] attitude was considered ethically unjustifiable, or at best to be tolerated. But in the backwoods small citizen circumstances of Pennsylvania in the eighteenth century, where business threatened for simple lack of money to fall back into barter, where there was hardly a sign of large enterprise, where only the earliest beginnings of banking were to be found, the same thing was considered the essence of moral conduct, even commanded in the name of duty." [p74, Weber 1930 [English translation]]
} 
with standing armies. This is not only because of repugnance towards the fact that mercenaries kill for pay rather than for state-sanctioned duty or patriotism. But that such repugnance plays a role is strongly suggested by the lesser protection mercenaries receive under international law such as the Geneva Conventions. ${ }^{12}$

Some markets are banned or limited in some times and places for combinations of reasons that include repugnance, but also include concerns about negative externalities (some of which arise because of the repugnance that third parties feel). For example, limits on prostitution or pornography depend at least in part on revulsion at commercializing sex, which is also an essential element of romance, marriage, and procreation. ${ }^{13}$ But there is also concern about the negative effects pornography or commercial sex may have on the neighborhoods where it is sold, e.g. on unwilling observers. Finally, prostitution and pornography may not involve only transactions between willing parties. (Thus, for example, the laws against child pornography are particularly severe, because it involves, or appears to involve, the abuse of children.)

Bans on commerce involving material judged to be obscene may also involve concerns about externalities, as in FCC regulations regarding certain words forbidden on radio and television broadcasts, or on voluntary regulations concerning whether children can see certain movies. But repugnance seems to be present even when externalities are minimal (as in the 1959 Post Office ban on sending copies of Lawrence's Lady Chatterley's Lover through the mail). ${ }^{14}$ Similarly, bans in various times and places on profane language may primarily concern externalities, but bans on blasphemy (for example on the sale of Rushdie's Satanic Verses in a number of Islamic countries) seem also to be aimed at limiting private consumption (and production).

Limits on the sale of alcohol and various drugs, and on gambling, may also be complicated in this way. ${ }^{15}$ When addiction is an issue, even apart from the negative externality on third parties (through e.g. increases in bankruptcy and crime), we may question whether the parties to the transaction are willing in the sense that we normally mean when we discuss voluntary transactions. (Some of the repugnance of addiction may be related to the repugnance of slavery and involuntary servitude.)

Some kinds of repugnance are also confounded with concerns about providing incentives for bad behavior. "Insurable interest" laws governing who can be the beneficiary of life

\footnotetext{
${ }^{12}$ Article 47 of the Protocol Additional to the Geneva Conventions of 12 August 1949, and relating to the Protection of Victims of International Armed Conflicts states "A mercenary shall not have the right to be a combatant or a prisoner of war." [add citation]

${ }^{13}$ Fiske and Tetlock (1997) talk about "taboo tradeoffs between different spheres of justice" to discuss why bringing to the market things that are customarily accomplished e.g. within families may seem inappropriate or worse.

${ }^{14}$ See e.g. Fairman (2007) for the history and legal status of the word "fuck," and see Rembar (1968) for an account of the obscenity trials involving the books Lady Chatterley's Lover, The Tropic of Cancer, and Fanny Hill.

${ }^{15}$ The sale of alcohol was banned throughout the United States from 1920 to 1933 by the 18th amendment to the Constitution (Prohibition), which was repealed by the 21 st amendment. Individual states and counties still retain a variety of restrictions.
} 
insurance are good examples. As discussed by Justice Oliver Wendell Holmes Jr. in a 1911 case, "The very meaning of an insurable interest is an interest in having the life continue, and so one that is opposed to crime." "The very idea of life insurance ('you want to set a price on your life, and then place a bet on your date of death?') seems to have had to overcome some initial repugnance (cf. Zelizer, 1979, on the early 1800s). Even today, insurance for small children raises questions about motives. And the insurance industry lobbies against Stranger (or Investor) Owned Life Insurance (SOLI) and "Viatical settlements" - third party markets and funds that purchase life insurance policies from elderly or terminally ill patients who wish to realize the cash value of their policies while still alive. The arguments against such funds often focus on the repugnance of having life insurance held by an entity that profits from deaths (in contrast to insurance companies, which make money when their customers live long lives. ${ }^{17}$

Repugnance to betting on life and death also shows up in other contexts. In July 2003, a proposed U.S. government-funded prediction market for terrorism related events was scrapped amidst much publicity, with the Senate Minority Leader (Tom Daschle) saying "I can't believe that anybody would seriously propose that we trade in death." Senator Barbara Boxer was quoted as saying "There is something very sick about it," and adding that those responsible should be fired. But in this discussion also, there was some concern about incentives, that terrorists themselves shouldn't be encouraged to play the market. ${ }^{18}$

To clarify our ideas on repugnance it may therefore be helpful to look at a relatively uncomplicated case, in which little else besides repugnance seems to be at work in limiting a market. Of the examples listed in Table 1, Dwarf tossing seems most like a market whose widespread banning involves no more than simple repugnance. This has been well documented through the jurisprudence of the United Nations' International Covenant on Civil and Political Rights.

\footnotetext{
${ }^{16}$ U.S. Supreme Court (1911): "A contract of insurance upon a life in which the insured has no interest is a pure wager that gives the insured a sinister counter interest in having the life come to an end. And although that counter interest always exists, as early was emphasized for England in the famous case of Wainewright (Janus Weathercock), the chance that in some cases it may prove a sufficient motive for crime is greatly enhanced if the whole world of the unscrupulous are free to bet on what life they choose. The very meaning of an insurable interest is an interest in having the life continue, and so one that is opposed to crime. And what, perhaps, is more important, the existence of such an interest makes a roughly selected class of persons who, by their general relations with the person whose life is insured, are less likely than criminals at large to attempt to compass his death.” [note: Justice Holmes' reference to T.J. Wainewright (aka J. Weathercock) is to a famous case of a murderer who sought to benefit from the life insurance of his victims.] Justice Holmes' opinion continues: "On the other hand, life insurance has become in our days one of the best recognized forms of investment and self-compelled saving. So far as reasonable safety permits, it is desirable to give to life policies the ordinary characteristics of property."

${ }^{17}$ Of course, sellers of annuities also profit from untimely deaths. For some flavor of the discussion, see e.g. the 2005 Wall Street Journal article by Rachel Silverman entitled "Letting an Investor Bet on When You'll Die; New Insurance Deals Aimed At Wealthy Raise Concerns."

${ }^{18}$ See CNN.com/InsidePolitics, “Amid Furor, Pentagon Kills Terrorism Futures Market,” July 30, 2003.
} 
Dwarf tossing is an activity in which a large person throws a small person. The venue often is one in which alcohol is served. It is often a source of livelihood for the small person, with the large person paying for the privilege. While legal in many places, it is also sometimes banned by law. These outright bans suggest that the concern is quite different from occupational health and safety regulations that might attempt to regulate how to conduct such an event (e.g. by requiring the wearing of helmets and kneepads). For example, the summary of the Ontario Dwarf Tossing Ban Act of 2003 states simply "The Bill bans dwarf tossing in Ontario and makes in an offence to engage in dwarf tossing."

The matter came before the UN Human Rights Committee after the French Ministry of the Interior, in 1991, issued a statement saying that "dwarf tossing should be banned on the basis of, among other things, article 3 of the European Convention for the Protection of Human Rights and Fundamental Freedoms." After bans were subsequently enforced in some municipalities, a French dwarf, who had been employed by a company called Société Fun-Productions, successfully sued in French courts to have the bans overturned. However the bans were upheld on appeal in 1995 by the French Council of State on the grounds that "dwarf tossing... affronted human dignity..." The dwarf then brought his complaint to the UN, asserting that he was the victim of a discriminatory violation by France of his right to employment. The UN report further notes that he stated "that there is no work for dwarves in France and that his job does not constitute an affront to human dignity since dignity consists in having a job." However the UN committee found in favor of France, writing in part "The Committee considers that [France] has demonstrated...that the ban on dwarf tossing... did not constitute an abusive measure but was necessary in order to protect public order, which brings into play considerations of human dignity that are compatible with the objectives of the Covenant." Thus the UN, like the French Council of State, essentially concluded that dwarf tossing was itself such a repugnant act that it imposed a negative externality by diminishing human dignity, a public good.

\section{Repugnance is hard to predict}

The preceding examples help illustrate that repugnance, alone or in alliance with other objections, can impose serious constraints on various kinds of transactions. However, predicting when repugnance will play a decisive role is difficult, not least because apparently similar activities and transactions are often judged differently. For example, while dwarf tossing is repugnant in many places, wife carrying, another sport that involves persons of disparate stature, has well publicized North American and world championships. ${ }^{19}$ Similarly, many of us can still recall when the controversial position for which Larry Summers had apologized most was in the 1991 memo he signed as chief economist of the World Bank, suggesting that it would be efficient for polluting industries to be located in less developed countries. But that controversy occurred after the Clean Air Act was amended in 1990 to allow trading of rights to pollute (through tradable emissions entitlements), an efficiency enhancing measure that attracted little public controversy. Likewise, there are laws criminalizing kickbacks offered by vendors

\footnotetext{
${ }^{19}$ See e.g. the website of the world championships in Finland http://www.sonkajarvi.fi/?deptid=15136.
} 
to purchasing agents, but no restrictions on frequent flier miles given to business travelers, who book their flights in their capacity as purchasing agents for their companies. And while laws against various forms of "price gouging" remain on the books, and ticket scalping in particular remains illegal in many places, Ticketmaster has recently started auctioning some tickets just before the time of the event (see e.g. Smith and Silver, 2006).

Similarly, although adoption of a child involves many costs, payment to the birth mother for the child is widely regarded as repugnant, and forbidden (internationally by the Hague Convention on Intercountry Adoption, and in the United States by e.g. the Intercountry Adoption Act of 2000).. However, largely unregulated markets have developed for many forms of reproductive technology, from markets for sperm and eggs, to the hiring of surrogate mothers who have a fertilized egg implanted and carry out the pregnancy of a genetically unrelated child (cf Spar, 2006). ${ }^{20}$ In this case, technologies of different vintages seem to engender different reactions, but it can also be that newer technologies are repugnant when older ones are not. For example, food crops that have been modified by traditional methods of cross breeding do not seem to be widely repugnant anywhere, while food crops genetically modified by recombinant DNA technology are not accepted nearly as widely. ${ }^{21}$

Nevertheless, we can see some patterns influencing where repugnance influences markets.

\section{Repugnance of money, and views towards compensating organ donors:}

One often noted regularity is that some transactions that are not repugnant as gifts and inkind exchanges become repugnant when money is added to the transaction. ${ }^{22}$ The long repugnance to charging interest for loans seems to fall into this class, as do prohibitions on paying birth mothers of children put up for adoption, and perhaps prostitution. That is, loans themselves, and adoption, and love are widely regarded as good things, even when their commercial counterparts are regarded in a negative way. (Offering money is often regarded as inappropriate even when not repugnant; e.g. dinner guests at your home may respond in-kind, by bringing wine or inviting you to dinner in return, but they would likely not be invited back if they offered to pay for their dinner. ${ }^{23}$ And sometimes it can

\footnotetext{
${ }^{20}$ But see Ramsey, 1970 for concerns about reproductive technologies that were then just emerging.

${ }^{21}$ See e.g. the body of European Union regulatory regulation, cf. http://ec.europa.eu/food/food/biotechnology/gmfood/legisl en.htm

${ }^{22}$ Of course, sometimes laws or public outrage focus on monetary transactions only because they are easier to ban than non-monetary transactions. For example, the supporters of the law that forbids restaurants from selling horsemeat in California no doubt aren't trying to preserve the sanctity of the backyard barbecue; they find eating horses repugnant, but acted to ban it in part through the regulation of restaurants. And, quite distinct from issues of repugnance, there may be resistance to charging for goods that have previously been provided for free, e.g. for water or the right to drive in cities during rush hours.

${ }^{23}$ See e.g. Sandel (2005) who begins "My topic tonight is 'The Moral Limits of Markets.' My question is: Are there some things that should not be bought and sold, and, if so, why?" His talk was introduced by Stanley Hoffmann, who writes "The topic falls a bit between the cracks of business school professors, who often hate to raise ethical problems, and economists, who don't always know what ethical problems are!" See Leonard (2004) for one economist's reply.
} 
be the price that is repugnant: after a natural disaster it is often regarded as acceptable to sell supplies at their pre-disaster price, but as repugnant price-gouging to raise the price. $^{24}$ )

Concerns about the monetization of transactions seem to fall into three principal classes. One is a concern that putting a price on things and trading them might move some things (like human organs, and human beings themselves) into a class of impersonal objects in which they do not belong. ${ }^{25}$ Another concern is that offering substantial monetary payments might be coercive, i.e. might cause people to engage in transactions that they would not engage in for smaller payments, in a way that would leave some people, particularly the poor, open to exploitation from which they deserve protection. The third kind of concern, sometimes less clearly articulated, is that monetizing certain transactions that might not in themselves be objectionable may lead via a slippery slope to more repugnant transactions.

\section{"Objectification"}

Many people clearly regard monetary compensation for organ donation as something that transforms a good deed into a bad one. In both Western Europe and the United States, governments strongly encourage organ donation, but forbid monetary payments to donors or their heirs. For example, Article 21 of the Council of Europe's (2002) Additional Protocol to the Convention on Human Rights and Biomedicine, on Transplantation of Organs and Tissues of Human Origin states "The human body and its parts shall not, as such, give rise to financial gain," while the U.S. National Organ Transplant Act (NOTA) of 1984 states "it shall be unlawful for any person to knowingly acquire, receive or otherwise transfer any human organ for valuable consideration for use in human transplantation". ${ }^{26}$

The feeling that virtuous organ donations are transformed into immoral commercial transactions by the introduction of monetary payments is clearly enunciated in the writings and speeches of Pope John Paul II. In his 1998 encyclical letter Evangelium Vitae, the Pope mentions the donation of organs as a "particularly praiseworthy example" of an action that builds "an authentic culture of life" (paragraph 86). But in an address to transplant surgeons in Rome in 2000, he warned "any procedure which tends to commercialize human organs or to consider them as items of exchange or trade must be considered morally unacceptable, because to use the body as an "object" is to violate the dignity of the human person." The Pope's concerns about paying for organs thus seem similar to those of the United Nations Commission for Human Rights concerning dwarf

\footnotetext{
${ }^{24}$ Cf. e.g. Kahneman, Knetsch, and Thaler (1986).

${ }^{25}$ In the sociology literature, there is also a longstanding interest in how the introduction of money changes many kinds of social relationships and their meanings (cf. Simmel, 1990).

${ }^{26}$ Article 21 of the European legislation goes on to exempt from this prohibition compensation to donors for expenses and loss of earnings. The quoted clause of the U.S. 1984 NOTA has been widely interpreted as being specifically directed against monetary payments (and not to the subsequent development of kidney exchange, now sometimes also called "paired kidney donation" to help preserve this distinction). The NOTA also goes on to explicitly exempt payment of expenses directly incurred by organ donors (e.g. travel expenses).
} 
tossing: in both cases there is the feeling that an important public good, human dignity, is being infringed upon for private gain. The Lutheran Church in America (1984) expresses a similar sentiment.

I note in passing that other religious traditions view the matter very differently. The emerging Jewish consensus on live kidney donations, for example, is that donation of organs is a good thing, and that under some circumstances it would be allowable to offer and accept compensation. ${ }^{27}$ Avraham (2004, p271-2) reports the opinion of the eminent posek Rabbi Shlomo Zalman Auerbach that someone who sells a kidney with the intention of saving a life does a good deed "even if he would not have donated his kidney only to save life." But he goes on to note "...in spite of all that has been said above, it seems to me that it is the community that needs soul-searching for allowing a person to reach such a depth of despair that he must sell a kidney, either because of poverty, debts or the inability to pay for a relative's medical expenses."

I am less familiar with Islamic thought on the matter, but I surmise that it is in some respects similar, since the Islamic Republic of Iran presently allows live kidney donors to receive monetary payments (cf Bagheri, 2006, Ghods and Savaj, 2006).

\section{"Coercion"}

A different concern, quite common in the organ transplant literature and elsewhere, is that money may be coercive, so that allowing kidneys to be sold would reduce the autonomy of the poor and allow them to be exploited. Even in the absence of money, transplant surgeons are eager to avoid accepting organs from donors who may feel coerced, e.g. by family pressure. (Contract law too has a general concern with coercion, expressed in the idea that contracts may be voidable by the courts in case of coercion due to, among other things, "undue influence" by parties with special relationships. ${ }^{28}$ Interestingly, Ghods and Savaj, 2006, express the view that the availability of paid unrelated kidney donors in Iran has reduced the coercion of unpaid related donors.)

In a recent exchange, Gaston et al. (2006) proposed in the American Journal of Transplantation that it might be possible to avoid the repugnance of outright payments for kidneys, while "limiting financial disincentives in live organ donation," by providing

\footnotetext{
${ }^{27}$ While there is no central authority on the application of Jewish law to modern concerns such as transplantation, the most authoritative opinions are contained in various "responsa" or answers to particular questions by rabbis acting as legal "deciders" (poskim), whose authority arises from the respect of their peers. The consensus on the matter of live kidney donation, for example, seems to be that live donation is allowed (since it saves lives), but it is not required (since the donor becomes wounded and takes some risk to his own life), and hence it falls into the category of things for which compensation could be offered and accepted (unlike actions that are either forbidden or required). See e.g. Eisenberg (2006), Grazi and Wowlowelsky (2004), Kunin (2005), and Israeli (1997) who cite eminent modern poskim such as R. Shlomo Zalman Auerbach and R. Moshe Feinstein. (cf. Avraham, 2000 pp270-274 for detailed discussion of Rabbi Auerbach's views). All these discussions reflect the tremendous importance that Jewish law gives to saving a life (pikuach nefesh), which can overturn many more mundane prohibitions when lives are at stake.

${ }^{28}$ cf. Farnsworth (1990), section 4.20. I am not aware, however, of any part of contract law that views excessive monetary compensation as a source of coercion.
} 
a fixed package of benefits to kidney donors, including insurance, compensation for expenses and lost wages, and a fixed payment (they suggest $\$ 5,000$ ) to compensate donors for pain and suffering. In response, in an editorial in the same issue of the journal, Fox (2006) writes of the "moral cost of living donor inducements" that "While the proposed benefit may not be a deciding factor to the CEO of a Fortune 500 company, to someone earning only minimum wage, the compensation may represent several months' pay. To deny the potential of this proposal to "coerce an otherwise unwarranted decision to donate' reflects the folly of the privileged, not the reality of the poor." Similarly, Kahn and Delmonico (2004) summarize their opposition to buying and selling organs by saying "It is an unethical approach to shift the tragedy from those waiting for organs to those exploited into selling them."

This point of view is not restricted by any means to the transplant community. Money is viewed as potentially coercive also, for example, in the regulations concerning the use of human subjects for research. The National Bioethics Advisory Commission (2001), writes that paying subjects to participate in medical experiments may be coercive. ${ }^{29}$ They go on to say that, if an institutional review board is concerned that the subjects in an experiment may be economically disadvantaged, it may require, to protect the subjects from coercion, that the researchers reduce the payments they make to participants. ${ }^{30}$ Note the concern here is not to protect the research design against the possibility that rich and poor participants might self-select differently into the experiment for a given participation fee, but rather to protect low-income participants from being faced with such a high participation fee that they would feel that they had no choice but to participate.

"Slippery slope"

Concern that monetizing some transactions might lead to other changes in the status quo seems to lurk not far beneath many of the other more explicit concerns. I know surgeons who fear a commercial dystopia in which kidney sales would enter into contracts, e.g. as collateral, or as payment for other medical services, or to repay debts, or as means tests

\footnotetext{
${ }^{29}$ In contrast, experimental economists often think that paying subjects in economic experiments, based on their performance, is an essential element in creating an economic environment in the laboratory in which the experimenter can exercise some control over subjects' preferences (cf. Kagel and Roth, 1995).

${ }^{30}$ They write "Prospective participants might have an economic vulnerability when they have the cognitive capacity to consent but are disadvantaged in the distribution of social goods and services such as income, housing, or health care. This type of vulnerability heightens the risk that the potential benefits from participation in the research study might constitute undue inducements to enroll, threatening the voluntary nature of the choice and raising the danger that the potential participant's distributional disadvantage could be exploited. For example, offers of large sums of money as payment for participation or access to free health care services (for conditions not related to the research) could lead some prospective participants to enroll in a research study when it might be against their better judgment and when otherwise they would not do so. To safeguard against this vulnerability, IRBs should make certain that research offers a "reasonable choice" to prospective participants. This might be an easy assessment for the IRB reviewing a research study in which payment is involved, and the amount of payment could be reduced (emphasis added). However, it can be more difficult for the IRB when the potential benefits include access to free medical care or social or other services."
} 
for eligibility for social services and financial aid. ${ }^{31}$ Note that this concern is not altogether different from concerns about how legalizing certain kinds of voluntary transactions may change the terms of trade so as to disadvantage those who don't wish to participate in them. (Basu (2003) uses sexual harassment as an example, and argues that legalizing labor contracts that allowed harassment would put workers who did not wish to be party to such contracts at a disadvantage relative to the status quo in which such contracts are illegal. Similarly, for example, bans on polygamy might be understood as outlawing certain kinds of competition that would disadvantage some men and some women relative to the monogamous status quo, even while allowing others to engage in welfare-improving transactions.) Some of the opposition to monetary compensation for deceased donor organs seems also to be of the slippery slope variety, with the concern being that it might pave the way for live organ sales.

Accounts of black markets for kidney transplants lead to concerns about whether legal markets would inevitably be similar. In this connection, Schepper-Hughes (2003, p1645) summarizes the black market experience as follows. "In general, the circulation of kidneys follows established routes of capital from South to North, from East to West, from poorer to more affluent bodies, from black and brown bodies to white ones, and from female to male or from poor, low status men to more affluent men." She concludes (p1648) "The division of the world into organ buyers and organ sellers is a medical, social, and moral tragedy of immense and not yet fully recognized proportions."

A related concern is that monetary markets might crowd out altruistic giving, and that this might both reduce the supply of transplantable kidneys (Howard, this issue, IOM, 2006) and harm other characteristics of the live kidney transplantation process (cf.

Danovitch and Leichtman, 2006). ${ }^{32}$

\section{Other sources of repugnance towards paying for live donor kidneys:}

Although I have argued above that repugnance felt towards kidney sales shares characteristics with repugnance towards monetizing other kinds of transactions, there may also be some unique features.

Among these is that taking a kidney from a healthy donor is not the part of the live donor transplant transaction that most appeals to surgeons trained in the Hippocratic tradition of "first, do no harm." While live donor kidney transplants save lives, it is not the life of the donor that is being saved, although it is prototypically the life of someone the donor loves. A surgeon who is already overcoming some distaste for performing a nephrectomy (kidney removal) on a healthy person may find the distaste more difficult to overcome if he views himself as facilitating a donation with an entirely commercial motivation.

\footnotetext{
${ }^{31}$ These concerns are not limited to surgeons: living donor organ transplants play a prominent role in a number of fictional dystopias, both for children and adults, such as Ishiguro (2005 Never Let Me Go), Picoult (2004 My Sister's Keeper), and Farmer (2002 House of the Scorpion).

32 There is a related literature in economics and psychology concerned with the loss of intrinsic motivation that might accompany the introduction of monetary payments, see e.g. Gneezy and Rustichini, 2000.
} 
Overall, Boulware et al. (2006) report (on the basis of a telephone survey of randomly selected households), "The U.S. public is not generally supportive of incentives for [deceased organ donation], but is supportive of limited incentives for [live donation]. Racial/ethnic minorities are more supportive than Whites of some incentives. Persons with low income may be more accepting of certain monetary incentives."

\section{Some historical perspective}

To put the debate about organ donation into some historical context, consider the case of cadavers. When the British medical journal The Lancet published its first volume in 1824 , its pages reflected a lively concern that there were too few cadavers available for anatomy classes. The main source of cadavers was an illegal black market supplied by so called "resurrection men," and indeed an editorial by that name opens with the news that a reliable resurrection man had recently been arrested and sentenced to seven years transportation. The editorial goes on to suggest that the government policy of only allowing the bodies of executed murderers to be used for anatomy studies "tends to keep up...the prejudice which is at present so strong against the obtaining of bodies for dissection" (Lancet, 1824).

The situation has changed, slowly but profoundly. In Britain, the Anatomy Act of 1832 considerably expanded the source of legal cadavers for dissection. And today, there are widely viewed exhibits of dissected cadavers in museums around the world. ${ }^{33}$ There are also today legal, regulated international markets for various storable transplantable cadaver tissues (e.g. bones), that can be used in surgical procedures such as hip replacements (cf Mahoney, 2000). Opponents of regulated markets for organs will not be reassured by the fact that there have been some notable abuses in the market for cadaver tissues, including the widely publicized scandal (and subsequent prosecutions) associated with the fraudulent sale of some of the body parts of Alistair Cooke, host of the television show "Masterpiece Theater," who died at the age of $95 .{ }^{34}$

\section{Constraints on market design}

So far I have discussed resistance to certain kinds of transactions from a passive point of view, noting that it is a reasonably widespread phenomenon that has sometimes shaped which markets we see. As economists are more often able to help design successful markets and allocation procedures, we also encounter this kind of resistance in an active way. My colleagues and I have encountered it in helping design both markets that involve monetary transactions, like labor markets, and allocation procedures that do not, like allocating public school places to children. Our experience suggests that ideas about the inappropriateness of

\footnotetext{
${ }^{33}$ See e.g. www.bodyworlds.com, a set of exhibits that features partially dissected cadavers in careful poses. Needless to say, this continues to arouse some repugnance, although not at the level that prevents the company from obtaining cadavers, or the shows from attracting large audiences (see e.g. Barboza, 2006).

${ }^{34}$ See e.g. Bone (2006) which discusses how not only was the family authorization to harvest body parts falsified, but so were Cooke's age, and cause of death (thus interfering with medical decisionmaking on appropriate use of body parts).
} 
certain kinds of transaction, even when this inappropriateness falls short of outright repugnance, can constrain market design.

Starting first with labor markets, in which monetary payments (wages) are not at all repugnant, there are nevertheless questions about what kinds of negotiations between firms and workers are appropriate. Many markets for entry-level professionals have suffered market failures due to unraveling of the transaction times at which new employees are hired. Typically in these markets, the hiring date moves further and further in advance of employment, with firms making potential employees "exploding offers" with the effect of not allowing employees the opportunity to consider other opportunities before responding (cf. Roth and Xing, 1994, and Avery et al. 2000 for descriptions of a variety of markets in which this kind of unraveling occurred). ${ }^{35}$ Sometimes there is an opportunity to correct such market failures by creating clearinghouses that will provide a thick market (cf. Roth 1984, 1991, Roth and Peranson 1998). ${ }^{36}$

When Muriel Niederle and I were asked to help redesign the entry-level market for gastroenterologists in this way, one issue was whether the Gastroenterology professional societies would be willing to adopt a resolution that would allow applicants who had accepted early exploding offers, well before the date for the clearinghouse to operate, to subsequently decline these offers and participate in the clearinghouse. Many gastroenterologists felt that it would be unprofessional for future gastroenterologists to begin their careers by first accepting an offer, and subsequently declining it. But it was also widely felt that early exploding offers were inappropriate and anti-competitive, and should be discouraged. After much discussion, the four Gastroenterology professional organizations became convinced that allowing applicants to change their minds about exploding offers would make such offers unprofitable, so that very few such offers would be made and subsequently declined. This is what ultimately proved to be the case when the organizations adopted policies that made it easier for recipients of early offers to change their minds (cf. Niederle, Proctor, and Roth 2006, Niederle and Roth 2006). The relevance for the present essay is that much of the debate focused on the propriety of how offers should be made, and accepted or rejected.

Discussions about propriety are not always decided on the basis of welfare. Atila Abdulkadiroglu, Parag Pathak, Tayfun Sonmez, and I have encountered this at several junctures in designing public school choice allocation procedures (for which monetary payments would be widely regarded as inappropriate). In Boston, one of the ways that children are assigned priority to enter particular schools is if they have an older sibling already attending that school. We proposed two alternative designs for a strategy proof allocation procedure, one of which was adopted (cf. Abdulkadiroglu, Pathak, Roth, and Sonmez 2005, 2006). The procedure that was rejected would have produced welfare gains in cases in which two students would have preferred to each go to the school for which the other had a high priority. But this proposal was rejected because it would have allowed the

\footnotetext{
${ }^{35}$ Often with bad consequences for efficiency; see e.g. Niederle and Roth (2003), Frechette, Roth, and Unver (2006).

${ }^{36}$ Clearinghouses are also sometimes employed to fix market failures due to congestion (see Roth and Xing 1997, and Abdulkadiroglu, Pathak, and Roth 2005, 2006).
} 
"trading" of sibling priorities, and there was sentiment that this would be an inappropriate transaction, because sibling priorities in particular shouldn't be tradable, as they were assigned to families only to make it easier for them to have both children in the same school if that was their preference.

Similarly strong preferences were expressed in the course of the design of the New York City high school allocation procedure, adopted in 2003 (see Abulkadiroglu, Pathak and Roth 2005, 2006). A key question revolved around the fairness of different ways to accomplish randomized tie-breaking for schools that don't have preferences. Here too it appeared that issues about the appropriateness of certain kinds of transactions sometimes had the potential to trump welfare considerations.

This brings me back to kidney exchange, described in the introduction. While most of our scientific work on kidney exchange has been about how to organize efficient exchange, and most of our organizational work has focused on coordinating multiple transplant centers and developing a sufficiently thick market, my point in the present essay is simply that, unlike the buying and selling of kidneys, in-kind exchanges have not aroused a repugnant reaction. Indeed, the Roth et al. (2006) article reporting the success of a novel kind of exchange in New England appeared, without any negative reaction, in the same issue of the American Journal of Transplantation as the Gaston et al. (2006) proposal for modest payments, and the Fox (2006) editorial in reply.

Note that in-kind kidney exchange directly helps only people who already have a willing live donor, so it isn't a general solution to the shortage of transplantable kidneys. It appears that if we could organize on a national scale we might be able to do several thousand more transplants per year (instead of the dozens to which the newly formed regional exchanges are still presently limited).

It can therefore certainly be argued that work on other margins might have bigger effects on U.S. health care, e.g. allowing kidneys to be purchased, or convincing Americans to lose weight. Needless to say, work on one margin does not preclude work on others, nor should we allow the biggest goals to discourage work on more modest but more immediately achievable goals (or vice versa).

\section{Economists' voices in the debate about organ sales, and reaction to them}

Becker and Elias summarize the kinds of arguments with which economists (and others) often respond to these concerns. The claim that organ sales "objectify" people is met by noting that in labor markets generally, poorer workers tend to take more dangerous and less pleasant jobs, in return for wages, and that we mostly think they do not diminish their humanity by doing so. Similarly, the response to arguments about "coercion" is typically that voluntary transactions increase welfare (including the welfare of the seller, if the transaction is truly voluntary). And the response to "slippery slope" arguments is that markets can be regulated. Sometimes these arguments are supplemented by the 
observation that organ donation itself could be subjected to some of the objections made to organ sales, even with a ban on monetary payments. ${ }^{37}$

The role of repugnance per se is often regarded as a side issue. For example, RadcliffeRichards et al., (1998) summarize these arguments clearly and conclude their "case for allowing kidney sales" with the following paragraph: "The weakness of the familiar arguments [against kidney sales] suggests that they are attempts to justify the deep feelings of repugnance which are the real driving force of prohibition, and feelings of repugnance among the rich and healthy, no matter how strongly felt, cannot justify removing the only hope of the destitute and dying. This is why we conclude that the issue should be considered again, and with scrupulous impartiality."

It will not surprise readers who have gotten this far that these arguments against banning organ sales leave many opponents unpersuaded. In an article that focuses on skepticism about the possibility of a regulated market (with particular attention to the situation in Iran reported by Ghods and Savaj, 2006), Harmon and Delmonico (2006) write "The Transplantation Society, the American Society of Transplantation, the American Society of Transplant Surgeons, the European Union, Eurotransplant, the National Kidney Foundation, the World Health Organization, and more have long recognized the unethical realities regarding a regulated market, and each organization has consistently opposed it."

Readers who want to test their own potential repugnance to voluntary transactions by well-informed, consenting adults might note that most of the arguments designed to disarm repugnance to legalizing the sale of a kidney would also, in principle, apply to selling an eye, an arm, a leg..., or a heart.

\section{Conclusions:}

Repugnance can be a real constraint on markets. Which transactions are repugnant can change over time, but repugnance can also be persistent. Almost whenever I have been involved in practical market design, the question of whether certain kinds of transactions may be inappropriate has come up for discussion. ${ }^{38}$

To say that repugnance is a real phenomenon doesn't mean that it isn't sometimes deployed for strategic purposes by self interested parties (such as, perhaps, insurance companies opposing viatical settlements). ${ }^{39}$ Just as there can be other objections to markets that some people find repugnant, repugnance may sometimes be invoked to recruit allies who would not respond to a clear appeal to narrower motives such as rent seeking. But the very real

\footnotetext{
${ }^{37}$ For references to both sides of the debate, particularly in the medical literature, see McCarrick and Darragh (2003) and Nadel and Nadel (2005).

${ }^{38}$ One notable exception has been in my role as chair of the American Economic Association's, Ad Hoc Committee on the Job Market, which has implemented several changes in the market for new Ph.D. economists. As nearly as I can recall, our discussions have focused only on efficiency and incentives. (The other members of that committee are John Cawley, Philip Levine, Muriel Niederle, and John Siegfried.)

${ }^{39}$ Experiments show this clearly in the case of transactions thought to be unfair, see e.g. Roth and Murnighan (1982, 1983) and Roth, Malouf and Murnighan (1982).
} 
repugnance that some people feel (and the fact that very many people seem to find at least some transactions repugnant or otherwise inappropriate) means that economists interested in proposing and designing markets must sometimes take account of repugnance.

The debate over whether the sale of kidneys should be legalized is just one example among many in which repugnance plays a large role (recall Table 1). But because of its importance, the arguments on both sides have been presented with particular force and clarity. All parties agree it is urgently desirable to cure patients with end stage renal disease, and that the best current treatment is organ transplantation, particularly from live donors, and otherwise from deceased donors. The current situation in the United States involves long wait times for deceased donor kidneys by tens of thousands of patients without a live donor, difficult and costly palliative treatment by dialysis, and thousands of deaths while waiting. But opponents of organ sales find the prospect of a market for organs so repugnant as to be apparently worse than the current situation. Proponents of markets are correspondingly frustrated at the failure to adopt what they see as a feasible solution that could be implemented quickly.

One way of seeing the role that repugnance plays in this debate is to think about other possible solutions to the shortage of kidneys. If the technological barriers could be overcome that currently prevent transplanting pig kidneys into human patients, such "xenotransplants" would also end the kidney shortage. But no one supposes that this solution can be implemented quickly, because some technological barriers cannot be overcome quickly, if at all. I've argued in this essay that repugnance is similar to technological barriers in this respect. I would not like to guess whether repeal of the widespread laws against kidney sales is likely to happen more quickly than the advances in xenotranplantation that would make such sales unnecessary. ${ }^{40}$

This doesn't mean that economists should give up on the important educational role of pointing to inefficiencies and tradeoffs and their costs. Neither should we expect such arguments to immediately win every debate. Being aware of the sources of repugnance can only help make such discussions more productive (not least because it can help separate the issues that are fundamentally empirical-like the degree of crowding out of altruistic donations that might result from different incentive schemes - from areas of disagreement that are not primarily empirical).

And, just as economists and other proponents of legalizing kidney sales may not always take repugnance with sufficient seriousness, opponents of such sales often fail to directly address the costs of the current kidney shortage, borne directly by kidney patients, and indirectly by society as a whole. Fiske and Tetlock's (1997) phrase "taboo trade-offs" is apt. Although economists see very few tradeoffs as taboo, especially if they are big enough, non-economists often decline to discuss tradeoffs at all, preferring to focus on the repugnance of transactions like organ sales. We all have to figure out how to

\footnotetext{
${ }^{40}$ Of course, there can also be "technological" developments in the law, e.g. if the courts were to accept the proposition of Volokh (2007) that there exists a "medical right to self defense" that would make bans on organ sales unconstitutional. Popular repugnance often affects courts differently than legislatures; e.g. the ban on gay marriage was lifted in Massachusetts by a court interpreting the State constitution, not by new legislation.
} 
supplement our discussion of some of these issues to more directly engage the concerns of those who don't agree. (In this respect, I interpret John Paul II's comments quoted above as suggesting that he preferred to bear the costs of the current situation, hoping for a different solution, and fearing that the market solution would have costs in other realms, i.e. that it would diminish the 'culture of life' in other ways.)

No one can contemplate the costs to the sick and dying without sharing Becker and Elias' concern for a solution to the shortage of transplantable organs. The questions are, what kinds of solution are feasible and desirable, on what time scale, how to get from here to there, and what to do in the meantime?

More generally, behavioral economics has been concerned mostly with how individuals make choices. But the manner in which attitudes about the repugnance or other kinds of inappropriateness of transactions shape whole markets, and therefore shape what choices people face, may be one of the important ways that "behavioral" considerations affect the economy. 
Table 1

Markets in which some transactions are (somewhere, or were once) repugnant

- Human Remains

- Cadavers for anatomical study, deceased-donor organs, bone and tissue

- Live donor organs (kidneys, livers)

- Labor

- Indentured servitude, slavery

- Volunteer army, mercenary soldiers

- Discrimination on race, gender, handicap, marital status, etc.

- Reproduction, sex, and marriage

- Adoption

- Surrogate mothers, egg and sperm donation, abortion, birth control

- Egg donation for research (may not be compensated in MA)

- Prostitution, pornography

- Bride price, dowry, polygamy, gay marriage

- Words and ideas

- obscenity and profanity

- blasphemy

- Risk

- Life insurance ("insurable interest")

- for adults

- For children?

- Stranger (or Investor) Owned Life Insurance (SOLI) and "Viatical settlements" - third party markets and funds. ("dead pools")

- Gambling,

- prediction markets ("terrorism futures market")

- Finance

- Short selling, currency speculation

- Interest on loans

- Pollution markets:

- Title IV of the 1990 Clean Air Act Amendments (tradeable emissions entitlements)

- Summers' 1991 World Bank memo on dirty industries in LDC's

- $\quad$ Price gouging

- After disasters (e.g. Hurricane Katrina)

- Ticket scalping (ticket auctions?)

- Religion/Sports (amateur/professional)

- Sale of indulgences

- Endorsements/payments for amateur versus pro athletes

- Drugs and sports

- Food, drink, and drugs

- Horse, dog meat (illegal in CA, but legal in Europe, Asia...)

- Alcohol (Prohibition)

- Marijuana and narcotics

- Vote selling, bribery (frequent flier miles?)

- Dwarf tossing 


\section{Bibliography}

Abdulkadiroğlu, Atila, Parag A. Pathak, and Alvin E. Roth, "The New York City High School Match," American Economic Review, Papers and Proceedings, 95,2, May, 2005, 364-367.

Abdulkadiroğlu, Atila, Parag A. Pathak, and Alvin E. Roth, (2006), "Strategy-proofness versus Efficiency in Matching with Indifferences: Redesigning the NYC High School Match," in preparation.

Abdulkadiroğlu, Atila, Parag A. Pathak, Alvin E. Roth, and Tayfun Sönmez, "The Boston Public School Match," American Economic Review, Papers and Proceedings, 95,2, May, 2005, 368-371.

Abdulkadiroğlu, Atila, Parag A. Pathak, Alvin E. Roth, and Tayfun Sönmez, "Changing the Boston School Choice Mechanism," working paper, January 2006.

Avery, Christopher, Christine Jolls, Richard A. Posner, and Alvin E. Roth, "The Market for Federal Judicial Law Clerks", University of Chicago Law Review, 68, 3, Summer, 2001, 793-902.

Avraham, Avraham S. Nishmat Avraham, Even Ha'Ezer and Choshen Mishpat (Vol. 3), Medical Halachah for doctors, nurses, health-care personnel and patients, ArtScroll Halachah Series, Brooklyn, N.Y., Mesorah Publications, 2004.

Bagheri, Alireza "Compensated Kidney Donation: An Ethical Review of the Iranian Model" Kennedy Institute of Ethics Journal - Volume 16, Number 3, September 2006, pp. 269-282

Barboza, David, “China Turns Out Mummified Bodies for Displays,” New York Tmes, August 8, 2006.

Basu, Kaushik (2003), "The Economics and Law of Sexual Harassment in the Workplace" Journal of Economic Perspectives, 2003, vol. 17, pp. 141-157

Becker, Gary S. and Julio Jorge Elias "Introducing Incentives in the Market for Live and Cadaveric Organ Donations," Journal of Economic Perspectives, this issue.

Bone, James, "Undertaker admits stealing and selling Alistair Cooke body parts," Times Online, October 20, 2006, http://www.timesonline.co.uk/article/0,3-2412747_1,00.html

L. E. Boulware, M. U. Troll, N. Y. Wang and N. R. Powe (2006), "Public Attitudes Toward Incentives for Organ Donation: A National Study of Different Racial/Ethnic and Income Groups," American Journal of Transplantation 2006; 6: 2774-2785

California Penal Code, Section 598. http://www.leginfo.ca.gov/calaw.html 
Clean Air Act Amendments (1990), S.1630, Title IV, Acid Deposition Control. http://www.epa.gov/oar/caa/caaa.txt

Coleman, Peter J., Debtors and Creditors in America: Insolvency, Imprisonment for Debt, and Bankruptcy, 1607-1900 (State Historical Society of Wisconsin, 1974) reprint, Beard Books, (1999)

Council of Europe (2002), Additional Protocol to the Convention on Human Rights and Biomedicine, on Transplantation of Organs and Tissues of Human Origin Strasbourg, 24.I.2002. http://conventions.coe.int/Treaty/en/Treaties/Html/186.htm

Danovitch, Gabriel M. and Alan B. Leichtman (2006), "Kidney Vending: The 'Trojan Horse' of Organ Transplantation," Clinical Journal of the American Society of Nephrology, xxx...

Eisenberg, Daniel, (2006) "Live Organ Donation," Society Today, February, http://www.aish.com/societyWork/sciencenature/Live Organ Donation.asp

Fairman, Christopher M., "Fuck" (March 2006). Ohio State Public Law Working Paper No. 59 Available at SSRN: http://ssrn.com/abstract=896790 , Cardozo Law Review, 28, 2007, forthcoming.

Farmer, Nancy (2002), House of the Scorpion, Atheneum/Richard Jackson Books.

Farnsworth, E. Allan (1990), Contracts, Little Brown and Company, Boston.

Fiske, A. \& Tetlock, P. E. (1997). "Taboo trade-offs: Reactions to transactions that transgress spheres of justice.” Political Psychology, 18, 255-297.

Fox, M.D. "The Price Is Wrong: The Moral Cost of Living Donor Inducements," American Journal of Transplantation, 6, 11, November 2006, 2529-30.

Fréchette, Guillaume, Alvin E. Roth, and M. Utku Ünver, "Unraveling Yields Inefficient Matchings: Evidence from Post-Season College Football Bowls," 2006.

Gneezy, Uri and Aldo Rustichini "Pay Enough or Don't Pay at All," Quarterly Journal of Economics, 2000, 115(3), pp. 791-810.

Grazi, Richard V. and Joel B. Wolowelsky (2004), "Jewish Medical Ethics: Monetary Compensation for Donating Kidneys," Israel Medical Association Journal, 6, March, 1858.

Ghods and Savaj, 2006, "IRANIAN MODEL OF PAID AND REGULATED LIVING UNRELATED KIDNEY DONATION" Clinical Journal of the American Society of Nephrology, 
Galenson, David W. White Servitude in Colonial America: An Economic Analysis. New York: Cambridge University Press, 1981.

R. S. Gaston, G. M. Danovitch, R. A. Epstein, J. P. Kahn, A. J. Matas, M. A. Schnitzler, "Limiting Financial Disincentives in Live Organ Donation: A Rational Solution to the Kidney Shortage ," American Journal of Transplantation, 6, 11, November 2006, 2548-55.

Hague CONVENTION ON PROTECTION OF CHILDREN AND CO-OPERATION IN RESPECT OF INTERCOUNTRY ADOPTION, 29 May 1993, http://www.hcch.net/index_en.php?act=conventions.text\&cid $=69$

Harmon, William and Francis Delmonico (2006), "Payment for Kidneys: A Government Regulated System Is Not Ethically Achievable," Clinical Journal of the American Society of Nephrology,

Hirschman, Albert (1977), The Passions and the Interests: Political Arguments for Capitalism before Its Triumph, Princeton, NJ: Princeton University Press.

Howard, David H. "Producing Organ Donors: The Current System and Prospects for Reform," Journal of Economic Perspectives, this issue.

Institute of Medicine (IOM), Organ Donation: Opportunities for Action, Washington, D.C., National Academies Press.

Ishiguro, Kazuo (2005) Never Let Me Go, Knopf.

Israeli, Shaul, “Organ Transplants: Responsa," ASSIA - Jewish Medical Ethics, Vol. III, No. 1, January 1997, pp. 14-17, http://www.szmc.org.il/index.asp?id=97\&top=1\&page id=231.

John Paul II (1998), Evangelium Vitae, http://www.cin.org/jp2ency/jp2evang.html

John Paul II (2000), “Address to International Congress on Transplants,” Rome, August 29, http://www.cin.org/pope/organ-transplant-cloning.html

Kagel, John and Alvin E. Roth (1995), Handbook of Experimental Economics, Princeton University Press

Kahn, Jeffrey P. and Francis L. Delmonico (2004), “The Consequences of Public Policy to Buy and Sell Organs for Transplantation," American Journal of Transplantation, 4, 178-180.

Kahneman, Daniel, Jack Knetsch and Richard H. Thaler. "Fairness as a Constraint on Profit-Seeking: Entitlements in the Market" American Economic Review 76(4), (1986): 728-741. 
Kunin, J.D. (2005), “The search for organs: halachic perspectives on altruistic giving and the selling of organs," J Med Ethics 2005;31:269-272,

http://jme.bmjjournals.com/cgi/content/full/31/5/269

Lancet: RESURRECTION MEN. • DISCUSSION (unsigned editorial)

The Lancet, Volume 1, Issue 19, 8 February 1824, Pages 194-195

Leonard, Thomas C. (2004) "The Price is Wrong: Causes and Consequences of Ethical

Restraint of Trade." Journal des Économistes et des Études Humaines 14(2): pp. 133-150

Lutheran Church in America (1984), "Organ Donation: A Resolution," Adopted by the

Twelfth Biennial Convention of the Lutheran Church in America, Toronto, http://www.elca.org/jle/article.asp?k=341

MacDonald, H.P. (2005). Human Remains: Episodes in Human Dissection.

Mahoney, Julia D., "The Market for Human Tissue, Virginia Law Review, Vol. 86, No. 2 (Mar., 2000), pp. 163-223.

McCarrick, Patricia Milmoe, Martina Darragh, "Scope note 43: Incentives for providing organs,” Kennedy Institute of Ethics Journal. Mar 2003. Vol. 13, 1; p. 53-64.

Nadel, Mark S. and Caroline A. Nadel. 2005. "Using reciprocity to motivate organ donations." Yale Journal of Health Policy, Law and Ethics 5, pp. 293-325

National Bioethics Advisory Commission, "Ethical and Policy Issues in Research Involving Human Participants," Volume I, Report and Recommendations, Bethesda, Maryland August 2001, http://www.georgetown.edu/research/nrcbl/nbac/human/overvoll.html

Niederle, Muriel and Alvin E. Roth, "Unraveling reduces mobility in a labor market: Gastroenterology with and without a centralized match," Journal of Political Economy, 111, 6, December 2003, 1342-1352.

Niederle, Muriel and Alvin E. Roth, "Making Markets Thick: How Norms Governing Exploding Offers Affect Market Performance," July, 2006

Niederle, Muriel, Deborah D. Proctor, and Alvin E. Roth, "What will be needed for the new GI fellowship match to succeed?" Gastroenterology, January, 2006, 130, 218-224

Ontario Dwarf Tossing Ban Act, 2003, http://www.ontla.on.ca/documents/bills/37 parliament/session4/b097 e.htm

Office of the United Nations High Commisioner for Human Rights, Protocol Additional to the Geneva Conventions of 12 August 1949, and relating to the Protection of Victims 
of International Armed Conflicts (Protocol 1), Adopted on 8 June 1977 by the Diplomatic Conference on the Reaffirmation and Development of International Humanitarian Law applicable in Armed Conflicts, entry into force 7 December 1979, in accordance with Article 95, http://www.unhchr.ch/html/menu3/b/93.htm

Office of the United Nations High Commissioner for Human Rights, International Covenant on Civil and Political Rights, Communication No. 854/1999 : France. 26/07/2002. CCPR/C/75/D/854/1999. (Jurisprudence) http://www.unhchr.ch/tbs/doc.nsf/0/09d49050a9b34aaac1256c6e0031b919?OpenDocument

Picoult, Jodi (2004), My Sister's Keeper: A Novel, Washington Square Press.

Radcliffe-Richards, J., Daar, A.S., Guttmann, R.D., Hoffenberg, R., Kennedy, I., Lock, M., Seils, R.A., Tilney, N., [for the International Forum for Transplant Ethics] "The case for allowing kidney sales," Lancet, 06/27/98, Vol. 351, Issue 9120, 1950-52.

Ramsey, Paul Fabricated Man: The Ethics of Genetic Control, Yale University Press, 1970

Rembar, Charles The End of Obscenity: The Trials of Lady Chatterly, Tropic of Cancer, and Fanny Hill New York: Random House, 1968.

Roth, Alvin E. "The Evolution of the Labor Market for Medical Interns and Residents: A Case Study in Game Theory", Journal of Political Economy, Vol. 92, 1984, 991-1016.

Roth, Alvin E. "A Natural Experiment in the Organization of Entry Level Labor Markets: Regional Markets for New Physicians and Surgeons in the U.K.", American Economic Review, vol. 81, June 1991, 415-440.

Roth, A.E., Malouf, M., and Murnighan, J.K. "Sociological Versus Strategic Factors in Bargaining," Journal of Economic Behavior and Organization, Vol. 2, 1981, 153177.

Roth, A.E. and Murnighan, J.K. "The Role of Information in Bargaining: An Experimental Study," Econometrica, Vol. 50, 1982, 1123-1142.

Roth, A.E. and Murnighan, J.K. "Information and Aspirations in Two Person Bargaining", Aspiration Levels in Bargaining and Economic Decision Making, R. Tietz, ed., Springer, 1983

Roth, A.E. and E. Peranson, "The Redesign of the Matching Market for American Physicians: Some Engineering Aspects of Economic Design," American Economic Review, 89, 4, September, 1999, 748-780.

Roth, Alvin E., Tayfun Sönmez and M. Utku Ünver, "Kidney Exchange," Quarterly Journal of Economics, 119, 2, May, 2004, 457-488. 
Roth, Alvin E., Tayfun Sönmez, and M. Utku Ünver, “A Kidney Exchange Clearinghouse in New England," American Economic Review, Papers and Proceedings, 95,2, May, 2005, 376-380.

Roth, Alvin E., Tayfun Sönmez and M. Utku Ünver, "Pairwise Kidney Exchange," Journal of Economic Theory, 125, 2, December 2005, 151-188.

Roth, Alvin E., Tayfun Sönmez and M. Utku Ünver "Efficient Kidney Exchange:

Coincidence of Wants in a Structured Market," American Economic Review, forthcoming.

Roth, Alvin E., Tayfun Sönmez, M. Utku Ünver, Francis L. Delmonico, and Susan L. Saidman, "Utilizing List Exchange and Undirected Good Samaritan Donation through "Chain" Paired Kidney Exchanges," American Journal of Transplantation, 6, 11, November 2006, 2694-2705.

Roth, Alvin E. and Xiaolin Xing, "Jumping the Gun: Imperfections and Institutions Related to the Timing of Market Transactions," American Economic Review, 84, September, 1994, 992-1044.

Roth, A.E. and X. Xing "Turnaround Time and Bottlenecks in Market Clearing: Decentralized Matching in the Market for Clinical Psychologists," Journal of Political Economy, 105, April 1997, 284-329.

Ruethling, Gretchen (2006), “Chicago Prohibits Foie Gras,” New York Times, April 27.

Saidman, Susan L., Alvin E. Roth, Tayfun Sönmez, M. Utku Ünver, and Francis L. Delmonico, "Increasing the Opportunity of Live Kidney Donation By Matching for Two and Three Way Exchanges," Transplantation, 81, 5, March 15, 2006, 773-782.

Sandel, Michael J. (2005), “The Moral Limits of Markets," Bulletin of the American Academy of Arts and Sciences, with an Introduction by Stanley Hoffmann, Summer, 6-10.

Scheper-Hughes, Nancy (2003), "Keeping an eye on the global traffic in human organs," The Lancet, 361, May 10, 1645-48.

Silverman, Rachel Emma "Letting an Investor Bet on When You'll Die; New Insurance Deals Aimed At Wealthy Raise Concerns; Surviving a Two-Year Window," Wall Street Journal, May 26, 2005, D1.

Simmel, Georg, The Philosophy of Money (Routledge, London, 1990), second edition.

Smith, Ethan and Sara Silver (2006), "Hot Seat: To Protect Its Box-Office Turf, Ticketmaster Plays Rivals' Tune --- As Online Threat Crescendos, It Goes After Resellers With Auctions, Exchanges --- Artists Get Piece of the Action," Wall Street Journal, 12 September, A1. 
Spar, Debora L. The Baby Business: How Money, Science, and Politics Drive the Commerce of Conception. Boston: Harvard Business School Press, 2006.

U.S. Congress, Intercountry Adoption Act of 2000, Public Law 106-279.

U.S. Supreme Court, GRIGSBY v. RUSSELL, 222 U.S. 149 (1911), 222 U.S. 149, Decided December 4, 1911.

Volokh, Eugene, "Medical Self-Defense, Prohibited Experimental Therapies, and Payment for Organs" . Harvard Law Review, Vol. 120, April 2007 Available at SSRN: http://ssrn.com/abstract $=941868$

Weber, Max \{1930) The Protestant Ethic and the Spirit of Capitalism, translated by Talcott Parsons, Scribner's Sons, New York.

Viviana A. Zelizer Morals and Markets: The Development of Life Insurance in the United States, New York: Columbia University Press, 1979. 